$\xi^{2}=-1$

\title{
Trace elements characterisation in floodplain soils underlain by crystalline rocks, akure, southwestern Nigeria
}

\author{
Asowata I. T ${ }^{1}$, Omokolade O. G ${ }^{1}$ \\ ${ }^{1}$ Department of Applied Geology, School of Earth and Mineral Sciences Federal University of Technology, Akure \\ *Corresponding author E-mail: itasowata@futa.edu.ng
}

\begin{abstract}
The results of the floodplain soils study on the spatial distribution of selected trace elements in top soils $(0-30 \mathrm{~cm})$ and sub soils $(>30-$ $100 \mathrm{~cm}$ ) near Ala River, Akure metropolis, are reported. The objectives of this study are to determine the concentration of trace elements in the top and bottom soils, and identify the possible enrichment sources of these elements in the floodplain area. Forty two samples (top soil 21; sub soil 21) were collected for the study. The samples were air dried at room temperature, disaggregated and sieved using $53 \mu \mathrm{g}$ mesh size. The prepared samples were further digested using modified aqua regia of (1:1:1 $\left.\mathrm{HNO}_{3}: \mathrm{HCL}_{2} \mathrm{H}_{2} \mathrm{O}\right)$. The digests were subjected to elemental analysis using Inductively Coupled Plasma-Emission Spectrometry (ICP-MS). The trace elements concentration in ppm exhibited the following distribution pattern. Cu range in ppm from 6.0 - 53.0 mean 27.43; $\mathrm{Pb}, 10.0-165.0$, mean 58.43; $\mathrm{Zn}, 29.0-$ 479.0 mean 223.1; Ni, 10.0 - 20.0, mean 14.86; Co, 16.0 - 33.0, mean 24.29; Mn, 250.0 - 1615.0, mean 983.29; Th 9.0 - 19.0, mean 14.43; V, 35.0 - 89.0, mean 73.05; La 26.0 - 84.0, mean 56.76 and $\mathrm{Cr} 11.0-60.0$ mean 40.43. While the result for the sub soils range in ppm, Cu from 3.0 - 51.0, mean 21.24; Pb, 7.0 - 208.0, mean 56.33; Zn, 21.0 - 460.0. mean 149.14; Ni, 8.0 - 29.0, mean 13.76; Co, 12.0 - 37.0, mean 23.95; Mn, 138.0 - 2283.0, mean 806.43; Th 9.0 - 28.0, mean 17.48; V, 40.0 - 105.0, mean 68.71; La 25.0 - 96.0, mean 61.00 and $\mathrm{Cr} 12.0$ - 58.0 mean 35.38. The results of both the top soils and sub soils showed higher concentration metal enrichment than the average shale values. The relative elemental mean concentration is such that $\mathrm{Mn}>\mathrm{Zn}>\mathrm{V}>\mathrm{La}>\mathrm{Pb}>\mathrm{Cr}>\mathrm{Co}>\mathrm{Cu}>\mathrm{Th}>\mathrm{Ni}$ in that order. Elements such as $\mathrm{Cu}, \mathrm{Zn}, \mathrm{Pb}, \mathrm{V}, \mathrm{Mn}$, Th and $\mathrm{Cr}$ had relatively moderate to very strong correlation coefficient $(\mathrm{r}=0.540 .97)$ with each other, which apparently indicate that these elements are of same source of enrichment in the floodplain. $\mathrm{Pb}, \mathrm{Zn}, \mathrm{V}, \mathrm{La}, \mathrm{Th}$ and $\mathrm{Cr}$ are elements that are of significant environmental concerns.
\end{abstract}

Keywords: Akure Floodplain; Soil Geochemistry; Geospatial Map; Urban Population; ICP-MS.

\section{Introduction}

Floodplain soils, which are also referred to as alluvial soils, overbank sediments or levee sediments, occur along streams with variable water discharge, (Bolviken et al., 2004.) The area represent very interesting potion of the eco-system where very reasonable geochemical signature of past environmental events can be assessed, Ottesen et al. 1989, Bidovec, 1998; Rognerud et al. 2000; Ajala et al., 2014. Floodplains are potential repositories for a wide range of contaminants among which heavy metals represent by far the greatest threat to human health and environment. The release of metal-rich waste into such environment, often combines various anthropogenic sources such as mining operations, industrial and urban wastes, transport, agricultural activity, deforestation, to mention a few (Swennen and Van Der Sluys 2002). This impact can be observed from geochemical evaluation of overbank vertical profiles of deposits in the floodplain area of which the top layer of the vertical profile can be found to be of higher negative impact, Macklin et al. 1994, 2006; Swennen et al. 1994; 1998; Langedall and Ottesen 1998; Ciszewski 2002; Bølviken et al. 2004; Pavlovic et al. 2004; Cappuyns et al. 2006), or, generally, in depth-integrated surficial overbank sediment samples or topsoil developed on floodplains, Ottesen et al. 1989; McConnel et al. 1993; Ódor et al. 1997; Rognerud et al. 2000; Halamić et al. 2003; Romic and Romic 2003). Floodplain sediment or soil reflects the geochemistry of overburden in the entire upstream river basin. This is because fine-grained alluvium (silt and clay) is carried in suspension from eroded source materials over very long distances, and is finally deposited on the floodplain in low energy environments, Ottesen et al. 1989; 2000. This makes the sediments to be useful in the search for new mineral resources, in monitoring environmental change, and also in the prediction of potential environmental hazards.

In the interpretation of floodplain geochemistry, it is important that the geology of the catchment area (study area) is well understood. Most streams in south western Nigeria are derived from the basement complex rocks which covers about half of the landmass of the entire Nigerian landscape. The Nigerian basement complex forms part of the pan -African mobile belt and lies between the West African and Congo cratons and south of the Touareg Shield, (Rahaman, 1986; Adekoya, 2003).

Metals occur naturally in soil and sediments in small amounts, and life on earth has evolved to cope with only small exposure to these elements. Many industrial activities enriches metals like Lead ( $\mathrm{Pb})$, Zinc ( $\mathrm{Zn})$ Cupper $(\mathrm{Cu})$, Vanadium (V), Chromium (Cr). These can then end up in the earth (Hendershot, 2005). A large number of trace metals are transported to the oceans from natural sources. However, these natural sources are supplemented by releases from anthropogenic processes which, for some metals, can exceed natural in-puts (Manahan, 1991). Trace metals are found in the soil, water, and sediment compartments of the environment, but potentially the most 
hazardous environmental effects to human health arise when they enter the food chain (Ayodele and Oluyomi, 2011). Trace metals studies have been an area of active investigation over the years (Fatoki et al., 2002). They are important in many fields of human endeavour such as human and animal nutrition, human health and disease, geochemistry (Davies, 1992) and environmental pollution (Nriagu, 1986). All trace elements are toxic to living organisms at excessive concentrations but some are essential for normal healthy growth and reproduction by either plants and / or animals at low but critical concentrations (Alloway, 1995).

In Nigeria, increasing urban human population, indiscriminate dumping of both solid and liquid waste, high vehicular traffic density and industrialization are major contributors of Potentially harmful elements (PHEs) to the environment, Olatunji and Abimbola, 2010, Olatunji et al 2014, Asowata et al., 2015. It is not an uncommon sight to see liquid waste discharging from the drains of industries into canals and adjacent urban soils. Also, in most urban areas, indiscriminate dumping of solid wastes into the environment is common. With urban geochemical mapping, it should be possible to assess how these anthropogenic activities have modified the chemical environment of the urban area and to assess the health impacts, not only on humans, but also on animals and plants. (Abimbola et al., 2011)

Several works have been carried out on the trace elements characteristics in floodplain sediments and soils in places such as Kaner River, Southern Indian, Pramod et al. 2001, in sedimentary environments. Cawthorn, 2001, Lapworth et al., 2011; 2012 did establish from the study on floodplain that weathering from the underlying geology contributed much to the enrichment of trace elements in the sediments load. In Nigeria, though some work have been carried out on sediments of river beds and floodplain, Ajala et al., 2014, Igwe et al., 2005, Asowata et al., 2015, Akintola et al., 2013, Akinlolu and Akinade, 2011 and Davis 2015 were elements such as Cd, Cu, Mn, Mo, Ni, Pb, $\mathrm{Zn}, \mathrm{As}, \mathrm{B}, \mathrm{Cr}, \mathrm{Ag}, \mathrm{Ba}$, and Sn were studied using Inductively Coupled Plasma-Mass Spectroscopy, ICP-MS. The summary results shown that these elements were enriched as a result of anthropogenic effects. Such include industrial and domestic waste that are discharged indistriminately. These works were largely carried out in sedimentary environment such as Lagos lagoon, Lagos metropolis, Ogbem river near River Niger, (Igwe, et al.2005) and Eke-Mgbom area f Afikpo (Ajala et al., 2014). However, works on the Ala river floodplain geochemistry, specifically on trace elements assessments have not been evaluated. This river drains over 70\% of Akure metropolis which is underlain by the crystalline rocks, figure 1 and 2 of Southwestern Nigeria. The study area (floodplain) is adjacent to the main river called Ala and the adjoining tributaries. The floodplain is extensive, with relatively gentle slope to flat topography. It is this topographic characteristic that allow for deposition of eroded materials from the catchment area. The thickness of the sediments that have been deposited over a long time is relatively of between 3 to 7 meter. The area is essentially rich in organic materials and has high water retention due to the closeness to the river. These attribute makes farming activities rampant in the floodplain. Also, animal husbandry is a common practice in the area; these include the rearing of fish, snail, pigs and cattle, which is attributed to the easy accessibility to fresh grasses and water.

The climate of the study area is of Tropical Rain Forest type with distinct wet season between (April and October) and dry season (Harmattan season) between (November and March). The main rain-bearing system affecting the area is embedded in the easterly wind current. Rain falls in every month of the year but the months between March and November receive most of the fall during which rainfall in excess of $40 \mathrm{~mm}$ may be recorded on a single day. The average annual rainfall is $1400 \mathrm{~mm}$ (Ondo State Ministry of Economic Planning and Budget, 2010).

The annual mean maximum temperature is $33^{\circ} \mathrm{C}$ while the mean minimum is $18^{\circ} \mathrm{C}$. Evaporation is usually low from June through September, ranging from 3.3 to $4.0 \mathrm{~mm} /$ day. Sunshine duration is short (2.7 to $2.9 \mathrm{hrs} /$ day) during the month of July to September, while the relative humidity ranges from 5.0 to $90 \%$, depending on the season and the mean relative humidity is over seventy-five percent (Ondo State Ministry of Lands, Housing \& Environment, 2000; 2010). The objectives of this study are to determine the concentration of PHEs in the top and bottom soils, and identify the possible sources of PHEs in the study area

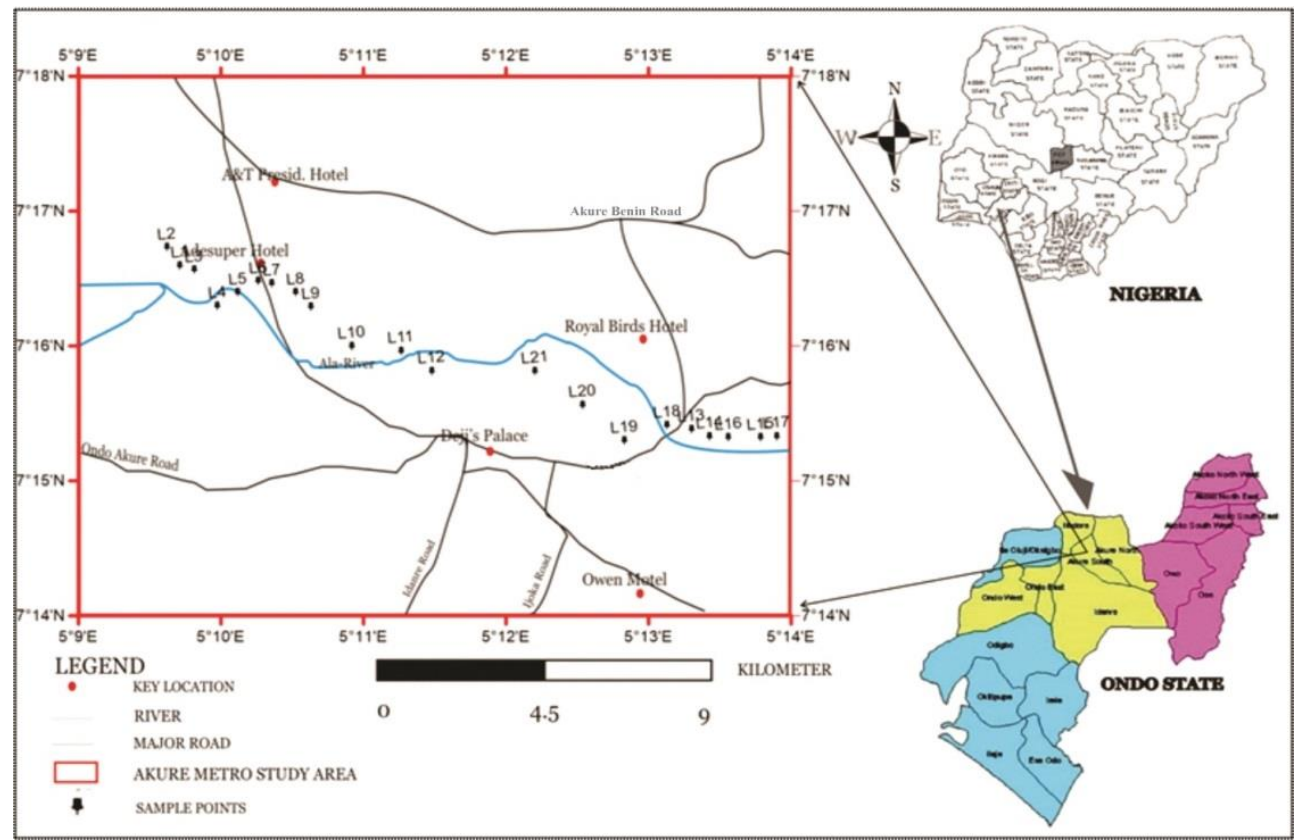

Fig. 1: Map of Akure Metropolis - the Study Area (Modified after Owoyemi, 1996)

\subsection{Local geological settings}

Akure is underlain by Precambrian basement complex rocks of South Western Nigeria, Rahaman, 1986. The major types of rocks in Akure are Quartzite, Granite gneiss, Granite, and Charnokite, Odeyemi, 1988; Owoyemi, 1996; Adekoya, 2003; NGSA, 2006). The granite rocks which are member of the older granite suit occupy about $65 \%$ of the total area of Akure. Three principal petrographic varieties are recognized, the fine-grained biotite granite, medium to coarse grained, non-porphyritic biotite - hornblende granite and coarse - porphyritic biotite- hornblade granite (Adekoya, 2003). The Charnockitic rocks of Akure constitute one of the petrologic units of the Pre- 
cambrian basement complex of Southwest Nigeria. On the outcrops are the occurrences of pegmatite, aplite and quartz veins as minor intrusions. They usually contain quartz + plagioclase + alkali feldspar + orthopyroxene + clinopyroxene + hornblende \pm biotite \pm fayalite . Accessory minerals are usually zircon, apatite, and iron ores (Olarewaju, 2006).

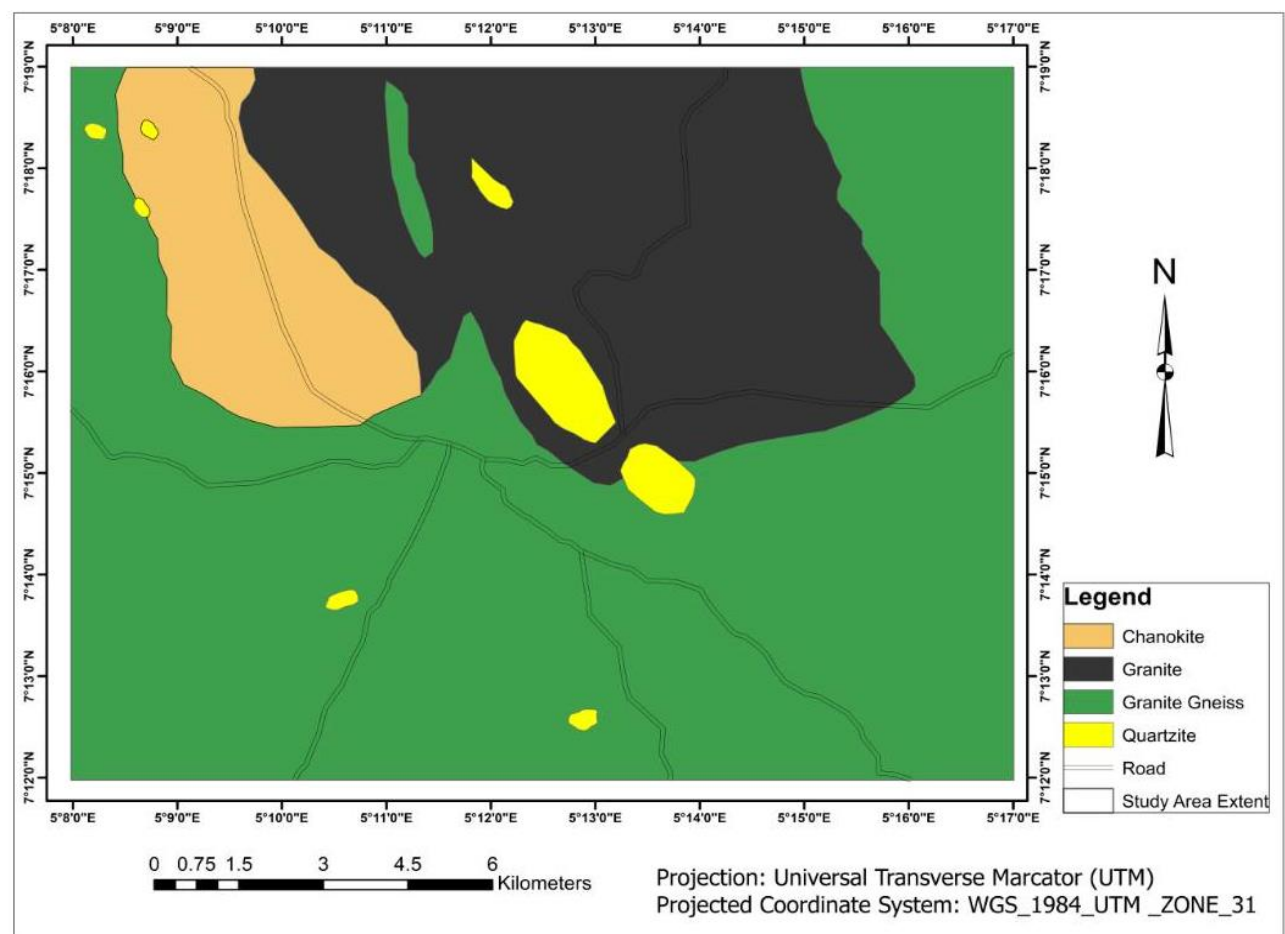

Fig. 2: Geological Map of Akure Area (Nigeria Geologic Survey Agency, 2006).

\section{Methodology}

\subsection{Sample collection}

Top soils and sub soils were collected from the floodplain at an interval of between 250 meters to 350 meters. The top soils were collected at a depth of $0-30$ centimetres $(\mathrm{cm})$, while the sub soils were collected at a depth of between $30-100$ centimetres $(\mathrm{cm})$. The soil samples $(\mathrm{N}=42)$ were collected using stainless-steel sampling auger of 1.5 meter length; which enable the sampling depth to successfully get to the required depth of one (1) meter. Three subsamples were collected and composited as one representative sample for every location for the top and sub soils samples. This was adopted in order to reduce point source contamination error.

\subsection{Sample preparation}

At the end of the sampling, the collected samples were air dried at room temperature. The soil samples were disaggregated and the shrubs and organic materials were removed before sieving. The soil samples were carefully sieved using $>53 \mu \mathrm{m}$ mesh size.

\subsection{Geochemical analyses}

Prior to geochemical analysis, $0.5 \mathrm{~g}$ of the soil samples were weighed into the digestion flask and extracted with modified aqua-regia (1:1:1 $\mathrm{HNO}_{3}: \mathrm{HCL}: \mathrm{H}_{2} \mathrm{O}$ ) for two hours at a temperature of $95^{\circ} \mathrm{C}$. The digested samples were then allowed to cool and filtered. The digests were subjected to elemental analysis using Inductively Coupled Plasma-Emission Spectrometry (ICP-MS) at the ACME Laboratories, http://www.acmelabs.com, Vancouver Canada. Quality control and assurance was guaranteed by the analyses of various certified reference materials and the analysis of duplicate samples.

\subsection{Geo-accumulation index}

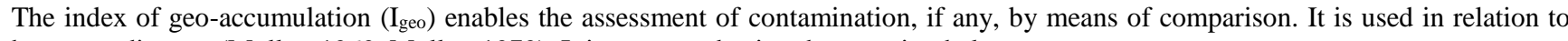
bottom sediments (Muller, 1969, Muller, 1979). It is computed using the equation below.

$\mathrm{I}_{\mathrm{geo}}=\log _{2}(\mathrm{Cn} / 1.5 \mathrm{Bn})$

Where I-geo represents the geo-accumulation index, $\mathrm{C}$ represents the measured concentration $\mathrm{n}$ of the element in the sediment, B represent the $\mathrm{n}$ background value (where, for this paper, $\mathrm{Bn}$ is the average of both the granite rocks and the average shale value.

\section{Result and discussion}

The results of the selected trace elements in both the top soils and sub soils showed varying concentration of these trace elements from one location to the other, as well as varying concentration from top soil which is from depth of $0-30 \mathrm{~cm}$ to below $30 \mathrm{~cm}$ to 1 meter. For the top soils, $\mathrm{Cu}$ range in ppm from 6.0 - 53.0 mean 27.43; $\mathrm{Pb}, 10.0$ - 165.0, mean 58.43; $\mathrm{Zn}, 29.0-479.0$ mean 223.1; Ni, 10.0 - 20.0, mean 14.86; Co, 16.0 - 33.0, mean 24.29; Mn, 250.0 - 1615.0, mean 983.29; Th 9.0 - 19.0, mean 14.43; V, 35.0 - 89.0, mean 73.05; La 26.0 - 84,0, mean 56.76 and $\mathrm{Cr} 11.0-60.0$ mean 40.43. The result for the sub soils range in ppm, $\mathrm{Cu}$ from 3.0 - 51.0, mean 21.24; $\mathrm{Pb}$, 
7.0 - 208.0, mean 56.33; Zn, 21.0460 .0 mean 149.14; Ni, 8.0 - 29.0, mean 13.76; Co, 12.0 - 37.0, mean 23.95; Mn, 138.0 - 2283.0, mean 806.43; Th 9.0 - 28.0, mean 17.48; V, 40.0 - 105.0, mean 68.71; La 25.0 - 96.0, mean 61.00 and Cr 12.0 - 58.0 mean 35.38, with their corresponding varying standard deviations (S.D) Table 1. The relative elemental mean concentration in the soils sample is such that $\mathrm{Mn}>\mathrm{Zn}>\mathrm{V}>\mathrm{La}>\mathrm{Pb}>\mathrm{Cr}>\mathrm{Co}>\mathrm{Cu}>\mathrm{Th}>\mathrm{Ni}$, figure 3 .

Considering the dispersion pattern of $\mathrm{Mn}$, it was found that relatively higher concentrations were found in locations; L8a, L10a and L13a, with concentration in ppm of 1499.0; 1615.01125 .0 respectively among other locations. In the same vein, there were higher concentration of Mn on the top soils as seen in location L14a (1060.0 ppm), L8a (1499.0 ppm) and L3a (250.0 ppm) compare to the sub soils in the same locations L14b (817.0 ppm), L8b (374.0 ppm) and L3b (138.0 ppm) among other locations, figure 4(f), this implies that the top soils is largely enriched in Mn than the sub soils, which may have been influenced by anthropogenic activities such mechanic workshop activities.

The concentration of $\mathrm{Zn}$ in ppm along the floodplain was such that relatively higher $\mathrm{Zn}$ were found in locations L21a (479.0), L20a (472.0) and L19a (455.0) respectively, which are largely within the city centre as against locations downstream, such as locations L3a (29.0) and L6a (47.8), suggesting higher influence of urban activities to the enrichment load on the floodplain. Base on the concentration pattern between the top and sub soils, it was observed that higher values were found in the top soils compared to sub soils, L20a (472.0), L20b (453.0), L21a (479.0), L21b (370.8), L13a (368.7) and L13b (334.0) among other locations. Though instances of higher values of $\mathrm{Zn}$ in the sub soils L4b (48.8) compare to the top soil L4a(45.0) were recorded, figure 4c. This does not in any way suggest that $\mathrm{Zn}$ element enrichment is from the bed rock, rather a possible sinking of $\mathrm{Zn}$ from the top soil to the subsoil, possibly due to prolong legacies of $\mathrm{Zn}$ element and effect of percolation through surface water to the sub soil.

The dispersion pattern for $\mathrm{Pb}$ was such that relatively higher concentration in ppm were found in locations, L20a (135.9), L21a (165.0), L19a (108.8), L13a (110.0), and L15a (98.7) as found in the upstream, which fall within the city centre as against Pb concentration in the downstream as found in locations L1a (9.8), L2a (15.9), figure 4b. Similarly, base on the variation in concentration between the top and sub soils, Pb exhibits relatively higher values in some locations in the sub soils; L21a (165.0) L21b (207.9), L18a (84.0), L18b (120.9) among other locations. But in some other locations, higher $\mathrm{Pb}$ values in (ppm) were recorded in the top soils compare to the subsoils, L19a (108.8), L19b (76.0), L17a (51.0) and L17b (28.8) among other locations, figure 4b.

Similarly, the trace elements concentrations were found to exhibit varying concentration from top soil to subsoil as seen in all the other selected elements, figure $4(\mathrm{a}-\mathrm{j})$. This implies that the enrichment of these trace elements which is higher in the top soil in many of the locations compare to the sub soils is possibly being enriched in trace elements concentration by anthropogenic activities such as mechanic workshop washout, transportation related activities, Agricultural (livestock rearing and use of fertilizer) activities among others. However, influences of bed rock geochemistry were found in some relatively fewer locations for some of the trace elements.

Relatively higher concentration of trace elements were also observed across the sampling location, particularly increasing enrichment of trace element from west to east suggestion increase in enrichment toward the urban centre, figure $5(\mathrm{a}-\mathrm{j})$. This phenomenon is visibly seen as exhibited by all the selected elements. This suggests that relatively higher concentration of potentially harmful elements in the study area have strong influence of urban and higher population related activities.

Table 1: Descriptive Statistics of Trace Element Concentration (Ppm) in Raw Floodplain Sediment (Indicating Top Soil and Sub Soil) of the Study Area

\begin{tabular}{|c|c|c|c|c|c|c|c|c|c|}
\hline \multirow{3}{*}{ Element } & \multirow{3}{*}{$\mathrm{N}$} & \multicolumn{3}{|c|}{ Range } & & \multirow{3}{*}{$\begin{array}{l}\text { Mean } \\
\text { Top soil(A) }\end{array}$} & \multicolumn{3}{|c|}{ Standard Deviation } \\
\hline & & Top soil(A) & & Sub soil(B) & & & Sub-soil(B) & Top soil(A) & Sub-soil(B) \\
\hline & & Min. & Max. & Min. & Max. & & & & \\
\hline $\mathrm{Cu}$ & 42 & 6 & 53 & 3 & 51 & 27.43 & 21.24 & 14.37 & 14.39 \\
\hline $\mathrm{Zn}$ & 42 & 29 & 479 & 21 & 460 & 223.10 & 149.14 & 174.22 & 154.23 \\
\hline $\mathrm{Ni}$ & 42 & 10 & 20 & 8 & 29 & 14.86 & 13.76 & 2.97 & 4.96 \\
\hline $\mathrm{Co}$ & 42 & 16 & 33 & 12 & 37 & 24.29 & 23.95 & 3.70 & 5.73 \\
\hline $\mathrm{Mn}$ & 42 & 250 & 1615 & 138 & 2283 & 983.29 & 806.43 & 373.33 & 506.53 \\
\hline $\mathrm{Th}$ & 42 & 9 & 19 & 9 & 28 & 14.43 & 17.48 & 2.73 & 3.54 \\
\hline $\mathrm{V}$ & 42 & 35 & 89 & 40 & 105 & 73.05 & 68.71 & 13.15 & 15.56 \\
\hline $\mathrm{La}$ & 42 & 26 & 84 & 25 & 96 & 56.76 & 61.00 & 12.16 & 18.53 \\
\hline $\mathrm{Cr}$ & 42 & 11 & 60 & 12 & 58 & 40.43 & 35.38 & 13.24 & 13.71 \\
\hline
\end{tabular}

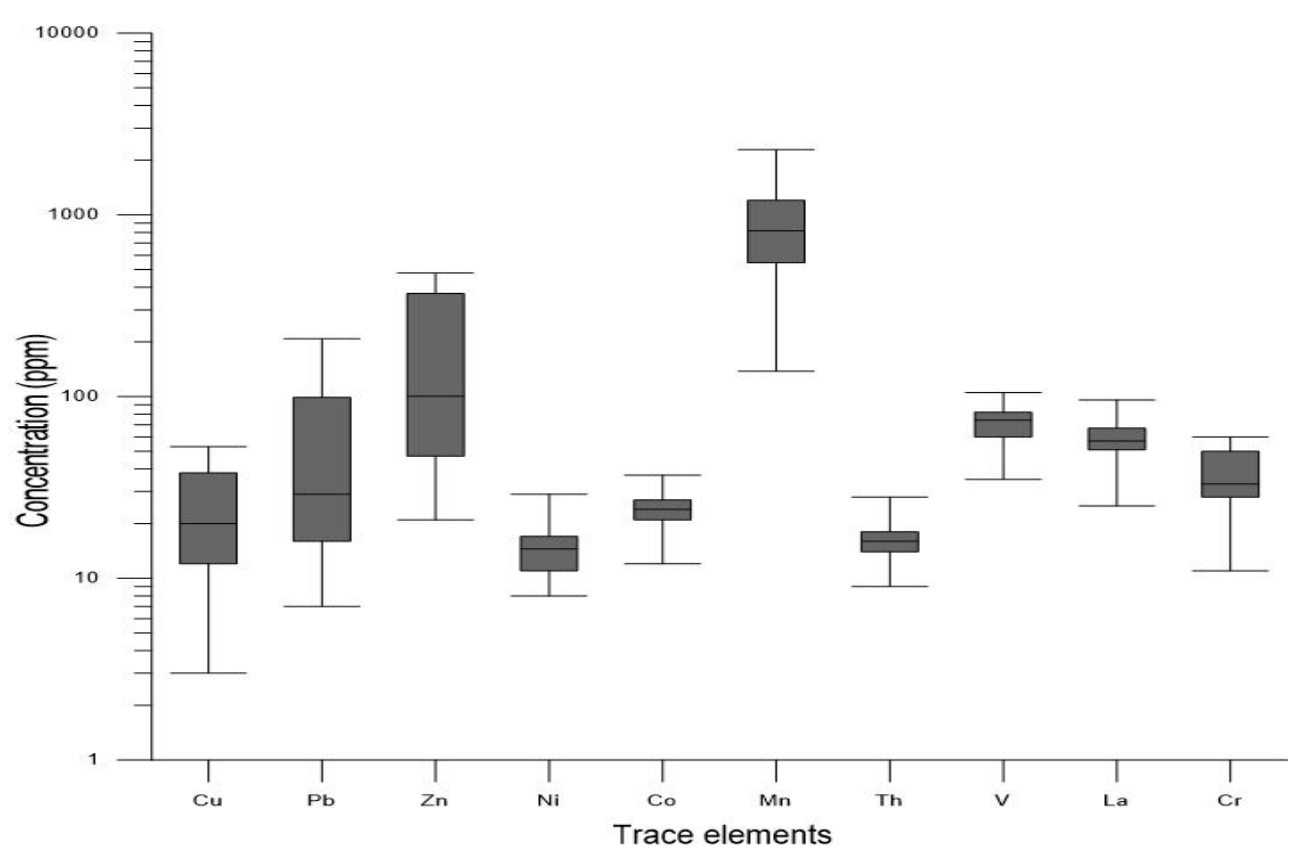

Fig. 3: Box Plots of the Total Concentrations (Ppm) of Trace Elements in Floodplain Soils. 
(A)
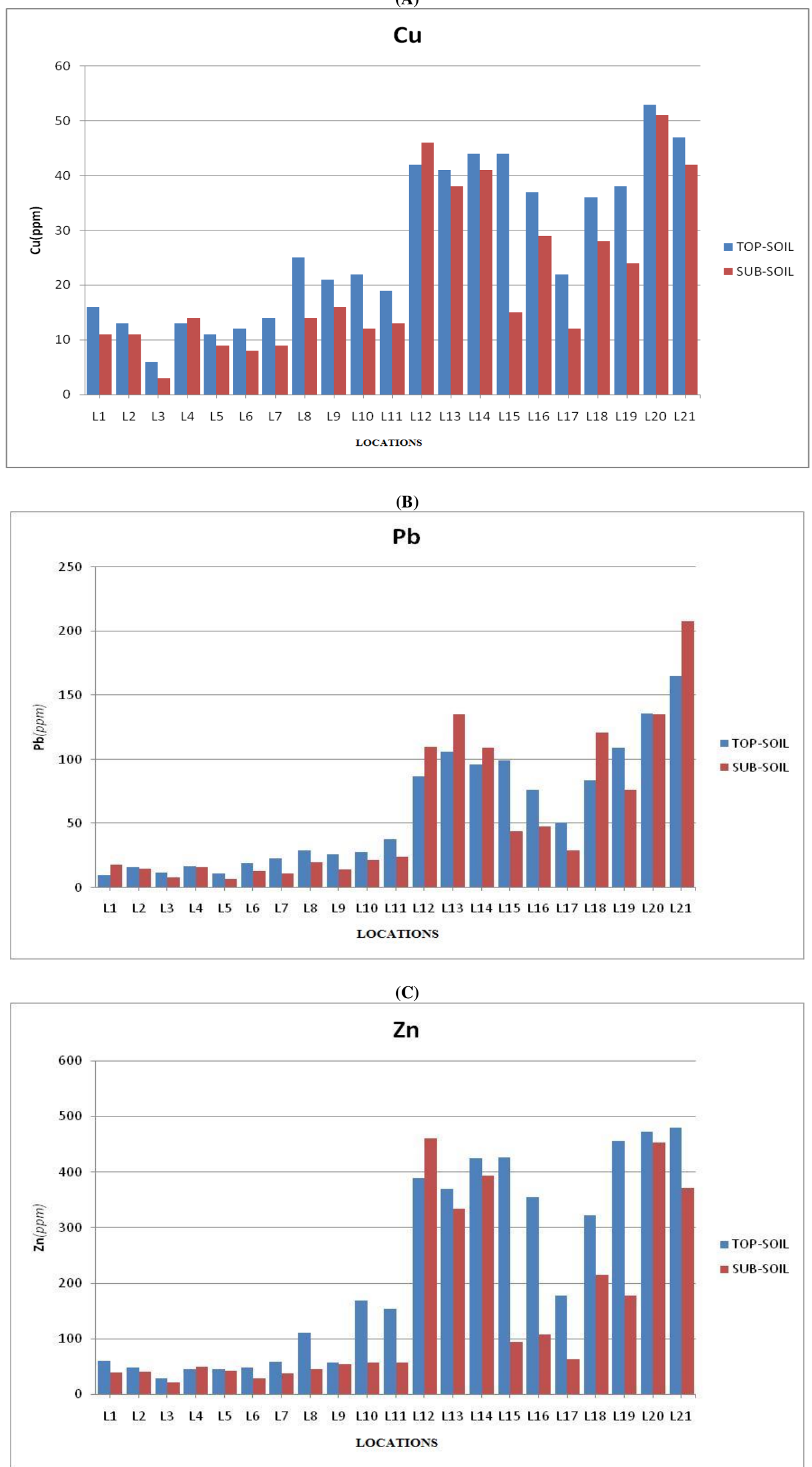
(D)

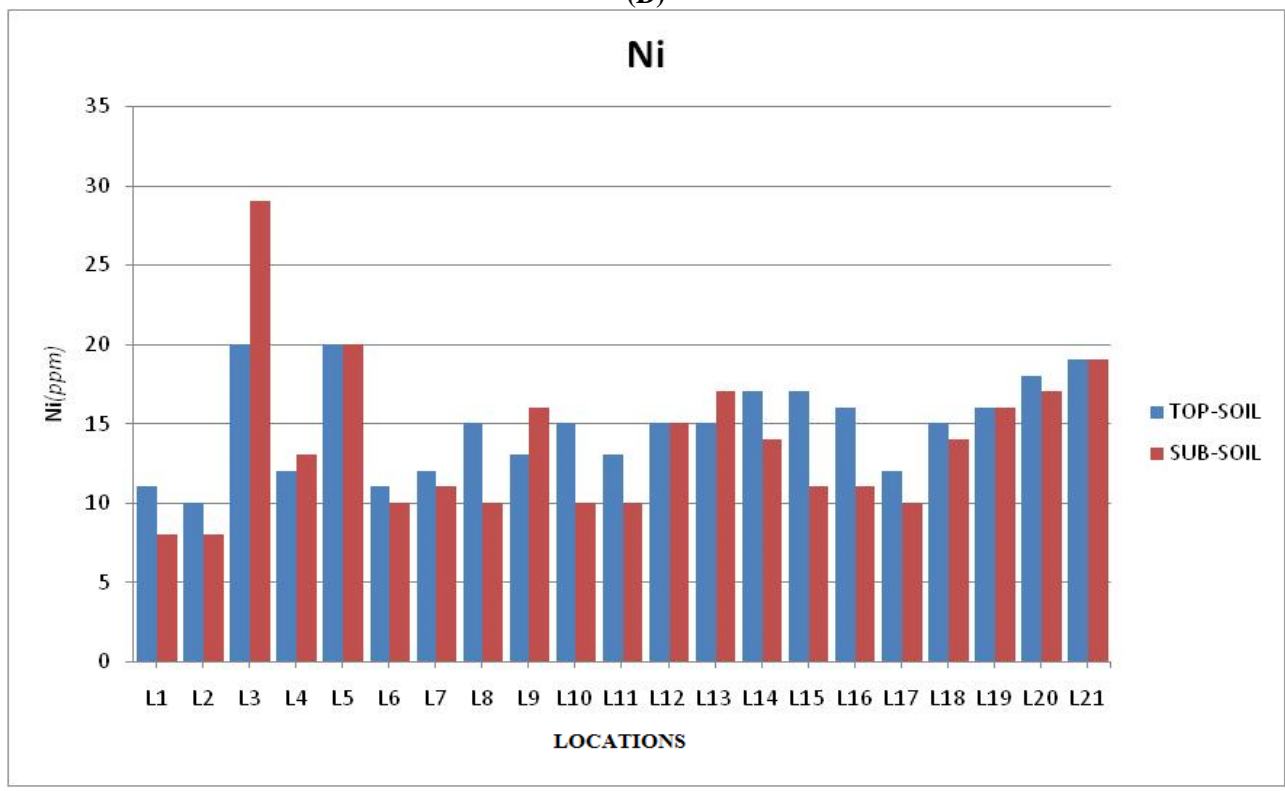

(E)

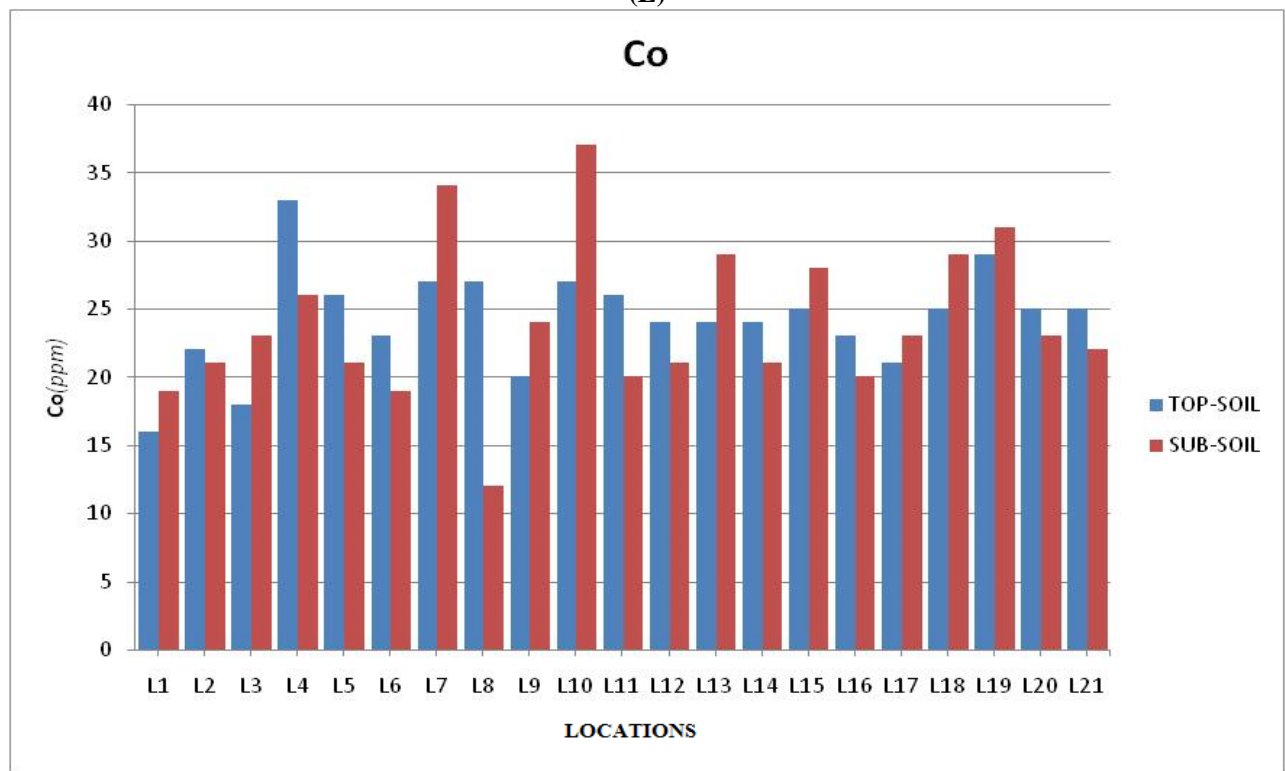

(F)

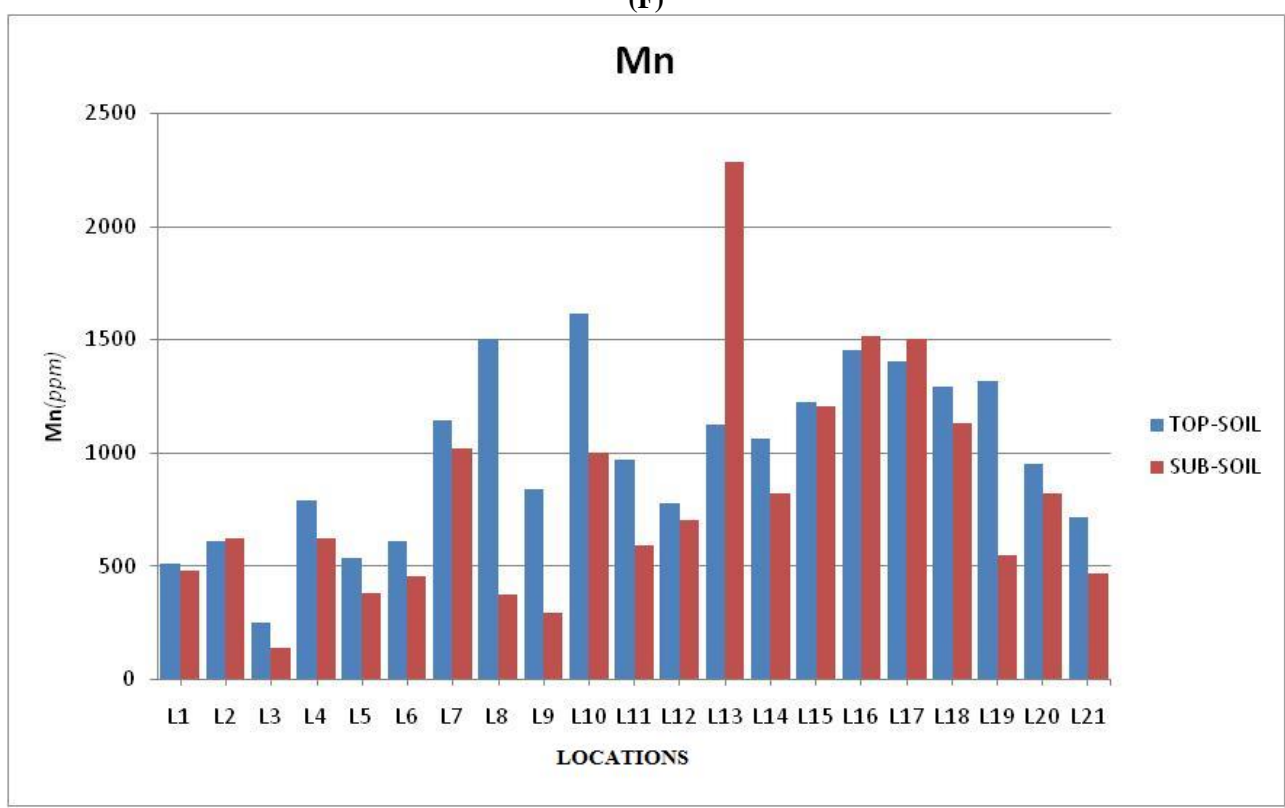


(G)
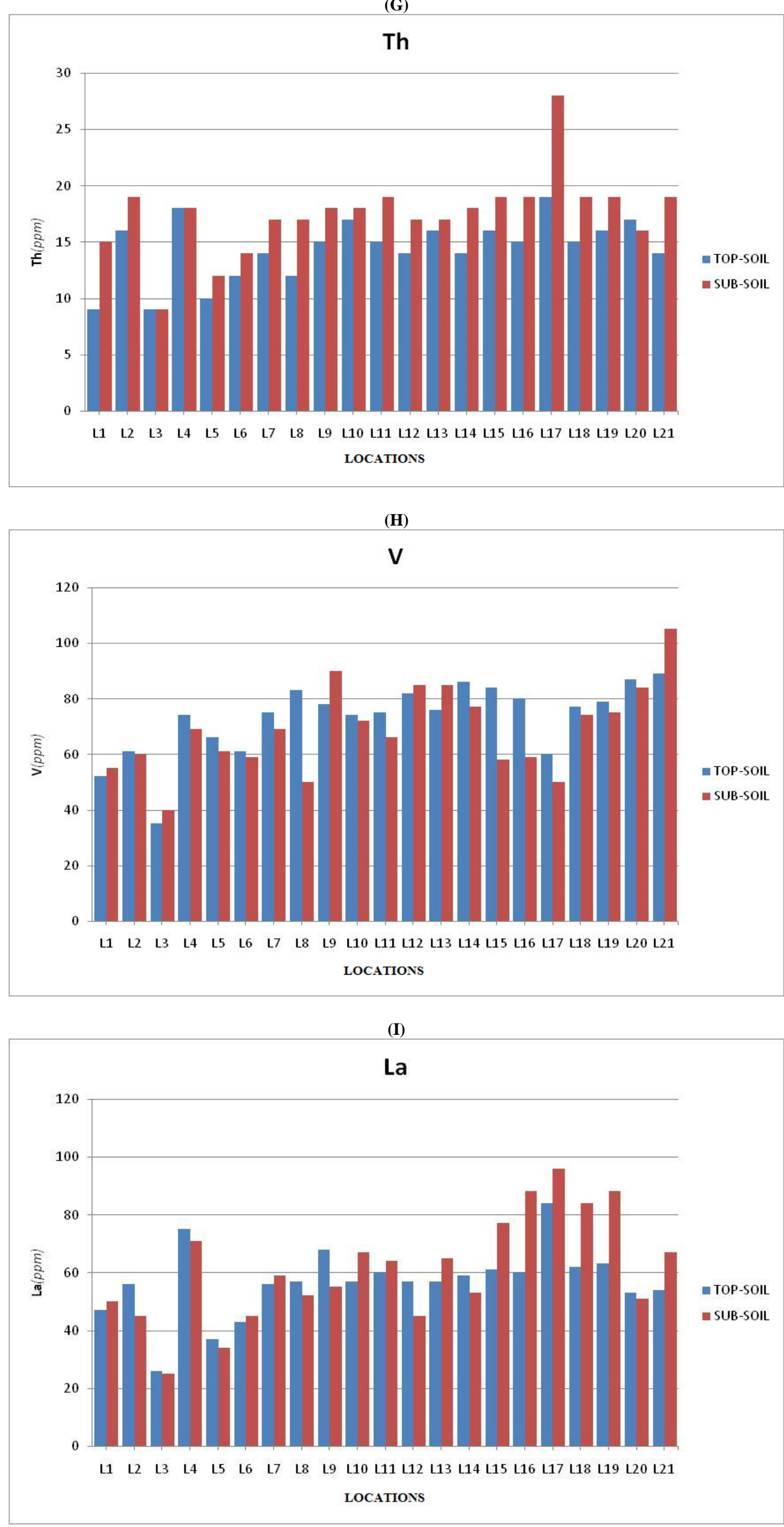


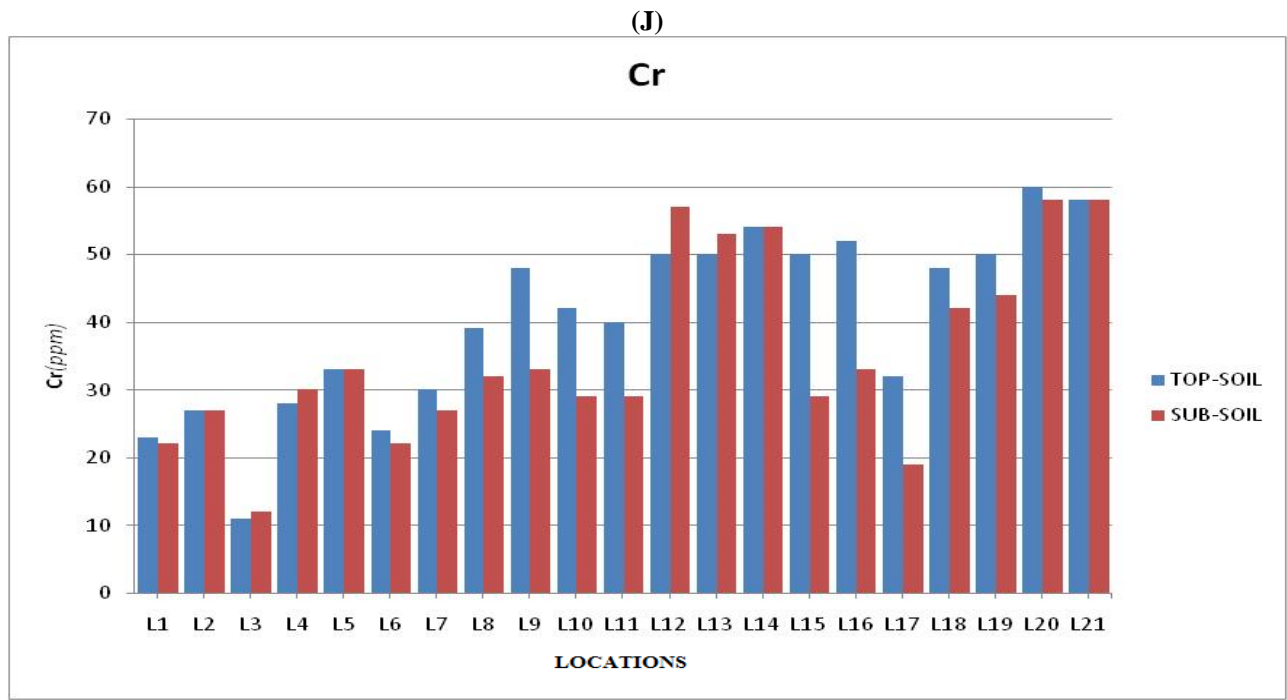

Fig. 4: (A- J): Concentration Frequency Distribution of Selected Trace Elements in Top-Soil and Sub-Soil of the Study Area.
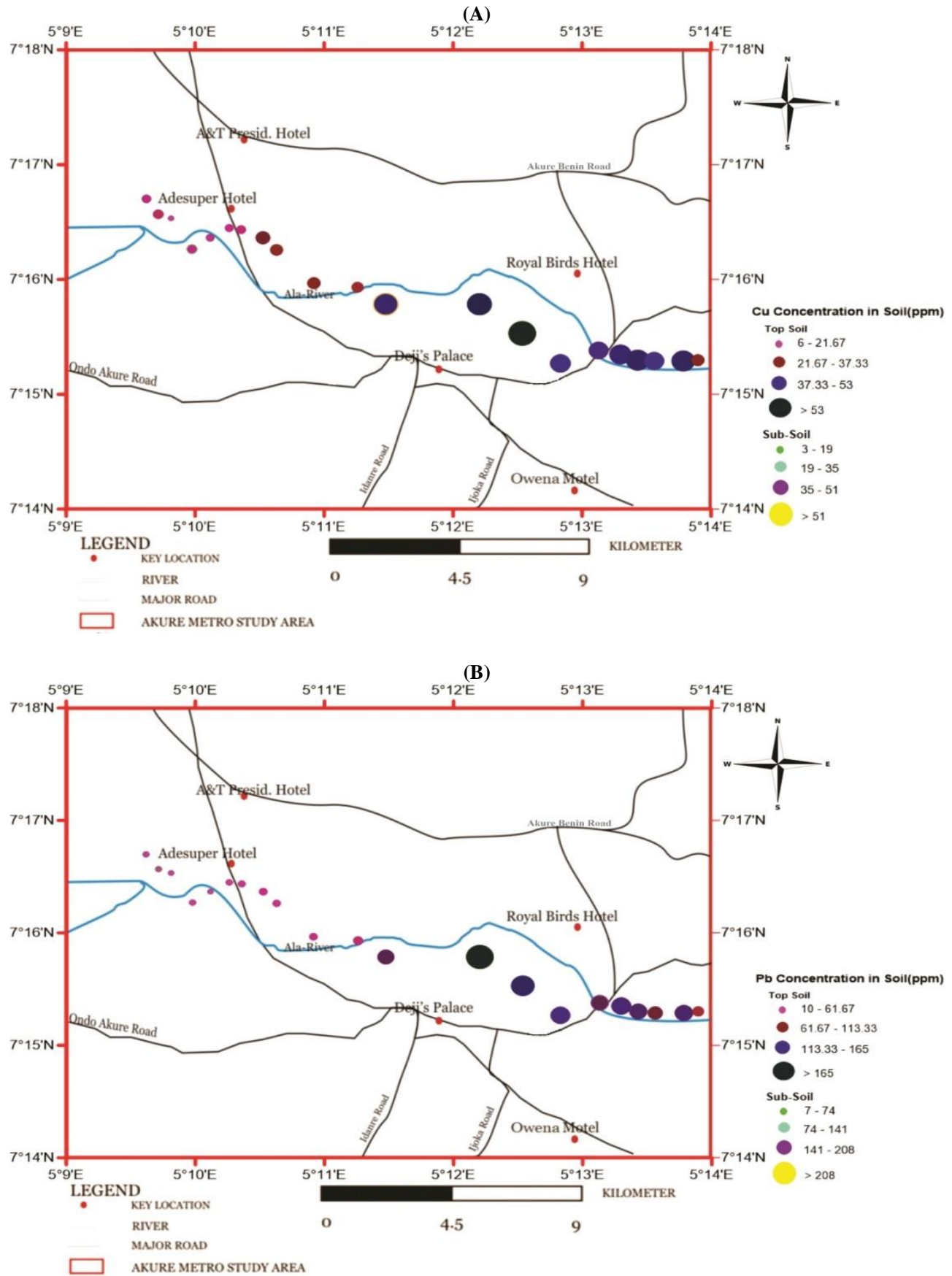

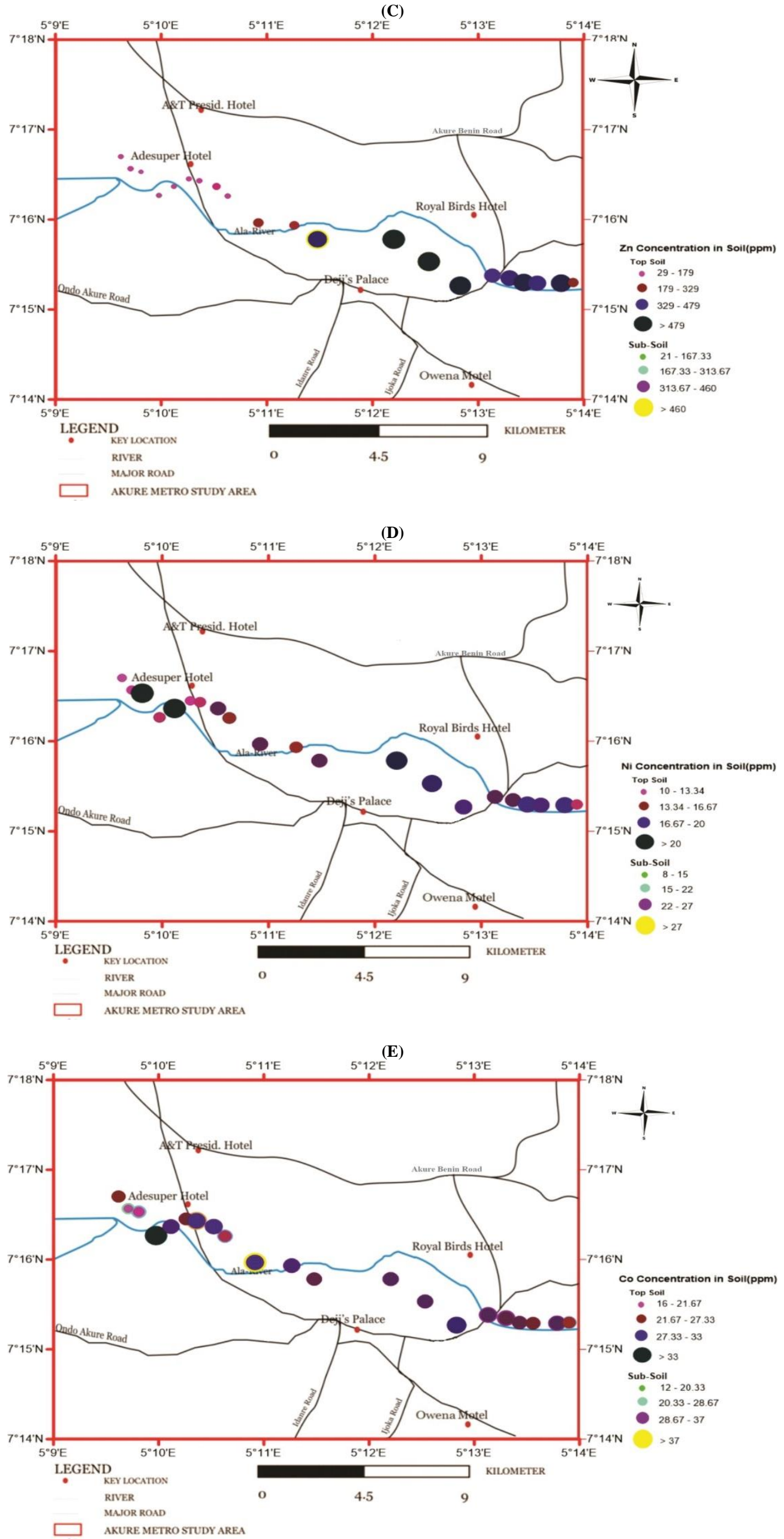

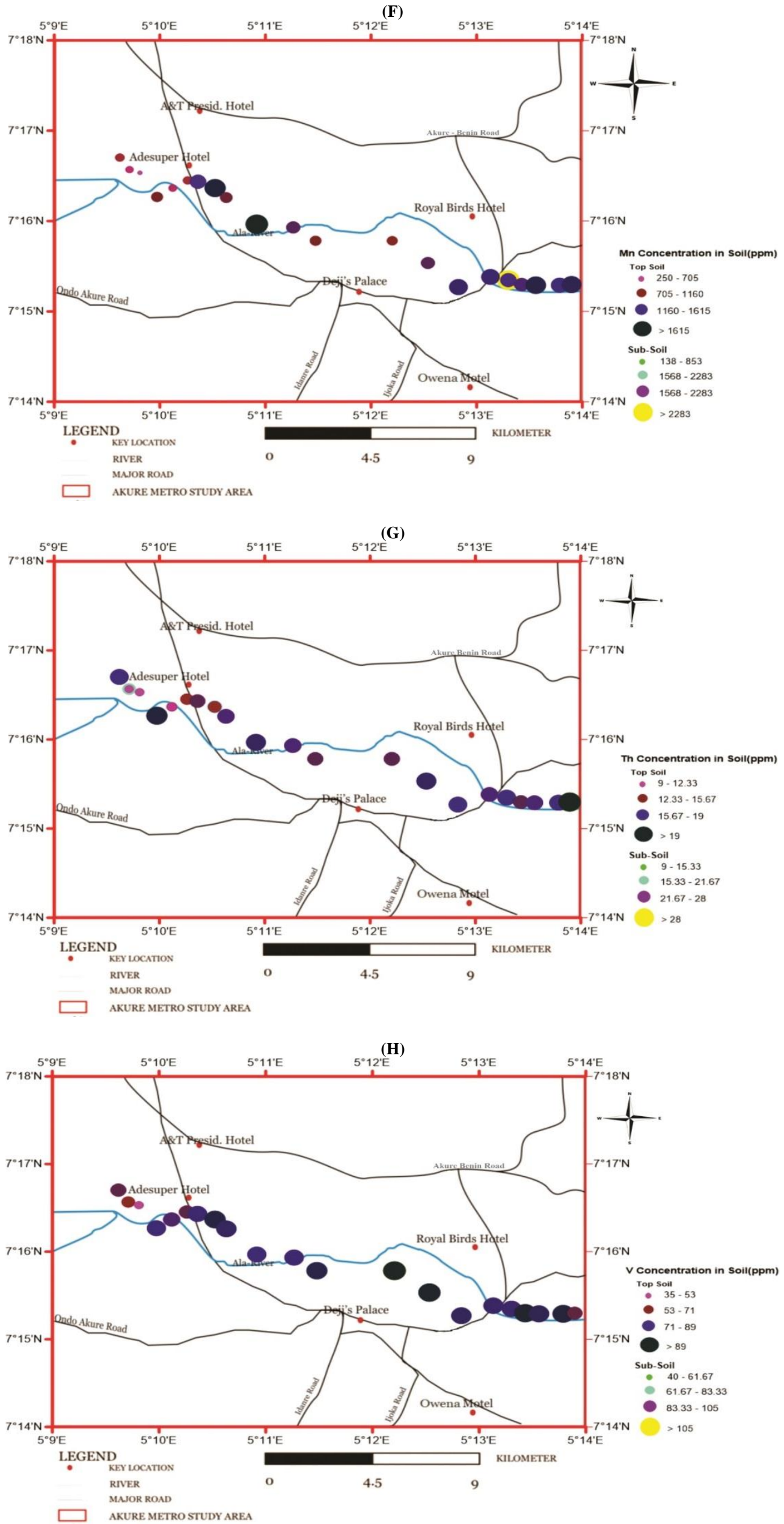

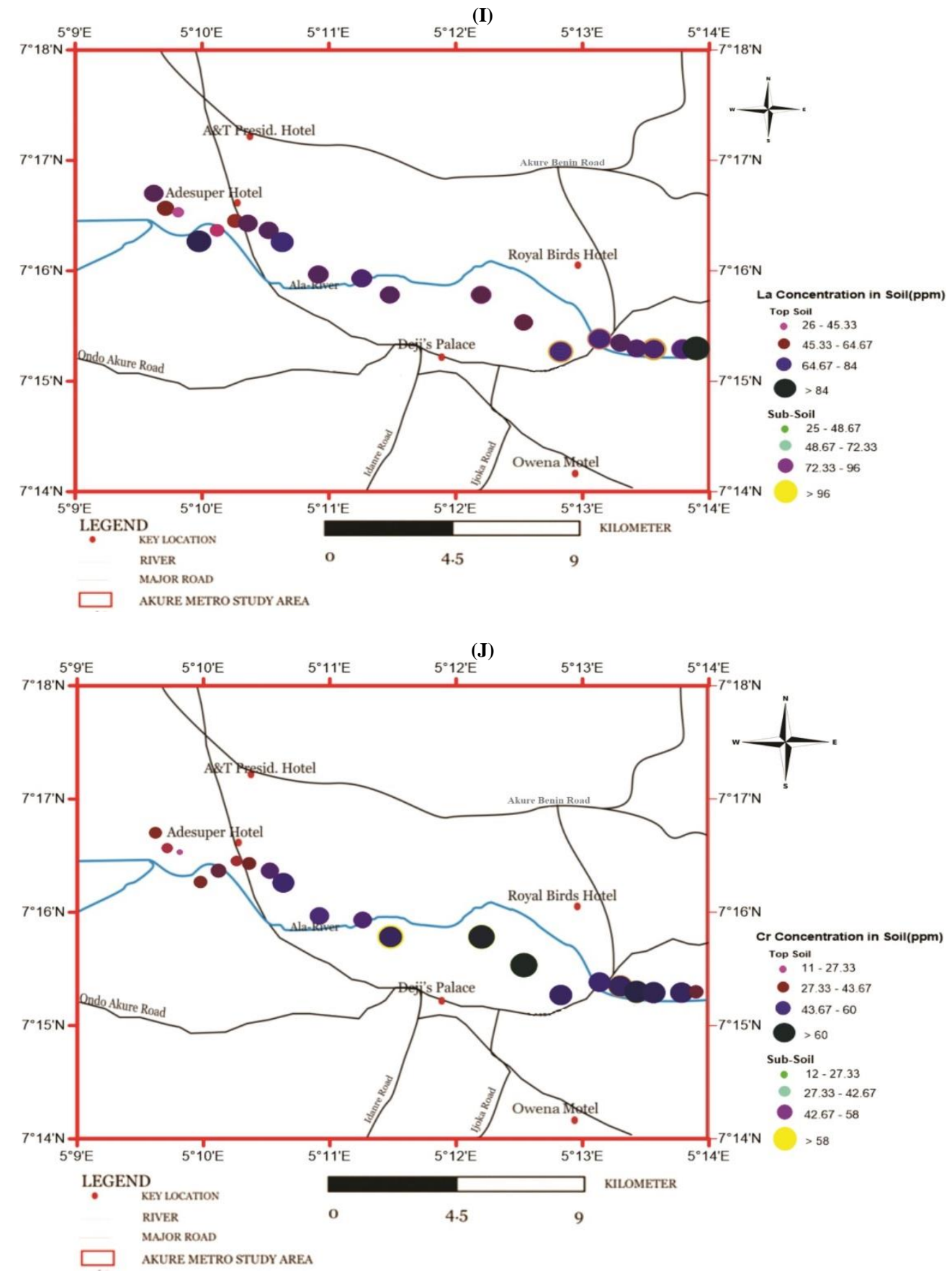

Fig. 5: (A - J): Spatial Distribution Map of Trace Elements in Top-Soil and Sub-Soil of the Study Area.

\subsection{Comparison of the mean concentration of selected elements in soils in selected cities and average shale values}

The mean elemental concentration in both the top soil and sub soil were compared with some selected published works some stream sediments as well as average granite concentration and average shale concentration, Table 2. From the results, $\mathrm{Cu}$, in both soils (top and sub) were lower than the results from Ala river, Lagos Lagoon, Average Share values among others but higher than average granite concentration. $\mathrm{Pb}$ concentrations in top soils and sub soils were found to be lower than results from Ala River and NdeMilli River among others, but higher than Lagos Lagoon, average shale value and average granite values. The mean $\mathrm{Zn}$ concentrations in top soils and sub soils were found to to be lower than the mean concentration in Ala River, NdeMilli and Nkisi Rivers, but higher than the mean concentration in Lagos Lagoon, shale and granite values. Similar variations in the other elements are exhibited as seen in Table 2. It was observed that influence of human population, urbanization and small to medium scale industries like mechanic workshops operations plays significant role in the relative variation of the enrichment of these elements in the study area.

Table 2: Comparison of Mean Concentration of Selected Potentially Harmful Elements in Sediments of Some Urban Areas, the Earth Crust and Granite Rocks of the World with This Study Area

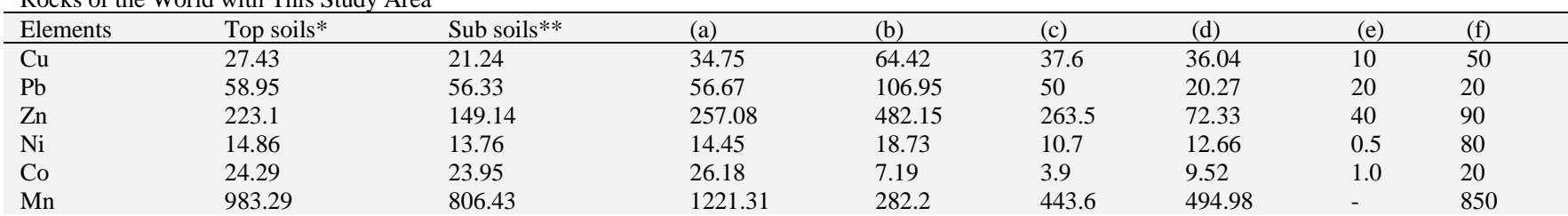




\begin{tabular}{|c|c|c|c|c|c|c|c|c|}
\hline Th & 14.43 & 17.48 & 12.06 & - & - & 3.29 & 17 & 1.0 \\
\hline V & 73.05 & 68.71 & 79.77 & 84.6 & 24.55 & 33.64 & 20 & 120 \\
\hline $\mathrm{La}$ & 56.76 & 61 & 48.63 & 111.8 & 14.7 & 26.97 & 25 & 40 \\
\hline $\mathrm{Cr}$ & 40.43 & 35.38 & 41.77 & 54.62 & 53.6 & 31.52 & 4 & 100 \\
\hline
\end{tabular}

${ }^{\mathrm{a}}$ Ala Stream sediment mean concentration after Asowata et al. 2015.

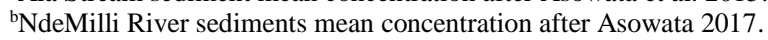

${ }^{\mathrm{c} N k i s i}$ River sediments mean concentration after Asowata 2017.

${ }^{\mathrm{d}}$ Lagos Lagoon sediment mean concentration after Olatunji and Abimbola 2010.

eAverage granite concentration after Levinson 1974.

${ }^{\mathrm{f}}$ Average Shale Concentration after Turekian and Wedepohl 1961.

*Top soils mean concentration, this study.

**Sub soils mean concentration, this study.

\subsection{Interelemental relationship between trace elements of floodplain samples}

Correlation matrix was calculated in order to evaluate the relationship between trace elements. Table 3 summarized the correlation matrix results of floodplain samples. Substances that showed a significant correlation $(\mathrm{p}<0.05)$ with $\mathrm{Cu}$ and $\mathrm{Pb}(\mathrm{r}=0.90), \mathrm{Zn}(\mathrm{r}=0.97), \mathrm{V}$ $(\mathrm{r}=-0.711)$ and $\mathrm{Cr}(\mathrm{r}=0.93)$. Lead significantly correlated with $\mathrm{Zn}(\mathrm{r}=0.90)$ and $\mathrm{Zn}$ significantly correlated with $\mathrm{Cr}(\mathrm{r}=0.90)$ and $\mathrm{V}$ $(\mathrm{r}=0.70)$. A significant correlation of $\mathrm{Mn}$ was also found with $\mathrm{La}(\mathrm{r}=0.54)$. So, from the above discussion it could be shown that most of the trace elements of the floodplain samples were significantly correlated with one another. From this, it could be said that their source was almost the same and which may be derived from chemical behaviour during transportation. Some of these relationships are shown in Figures 5 (a-e). From the moderate to stronger affinity level exhibited by these elements, it can be said that these elements are possibly from same sources of enrichment in the environment.

Table 3: Correlation Coefficients of the Trace Elements in the Study Area

\begin{tabular}{|c|c|c|c|c|c|c|c|c|c|c|}
\hline & $\mathrm{Cu}$ & $\mathrm{Pb}$ & $\mathrm{Zn}$ & $\mathrm{Ni}$ & $\mathrm{Co}$ & $\mathrm{Mn}$ & Th & $\mathrm{V}$ & $\mathrm{La}$ & $\mathrm{Cr}$ \\
\hline $\mathrm{Cu}$ & 1 & & & & & & & & & \\
\hline $\mathrm{Pb}$ & 0.90 & 1 & & & & & & & & \\
\hline $\mathrm{Zn}$ & 0.97 & 0.90 & 1 & & & & & & & \\
\hline Co & 0.05 & 0.11 & 0.09 & 0.07 & 1 & & & & & \\
\hline Mn & 0.37 & 0.28 & 0.33 & -0.14 & 0.39 & 1 & & & & \\
\hline Th & 0.12 & 0.21 & 0.09 & -0.46 & 0.21 & 0.37 & 1 & & & \\
\hline V & 0.75 & 0.71 & 0.70 & 0.19 & 0.37 & 0.30 & 0.18 & 1 & & \\
\hline $\mathrm{Cr}$ & 0.93 & 0.85 & 0.90 & 0.28 & 0.14 & 0.35 & 0.14 & 0.86 & 0.17 & 1 \\
\hline
\end{tabular}

(A) Pb vs. Cu

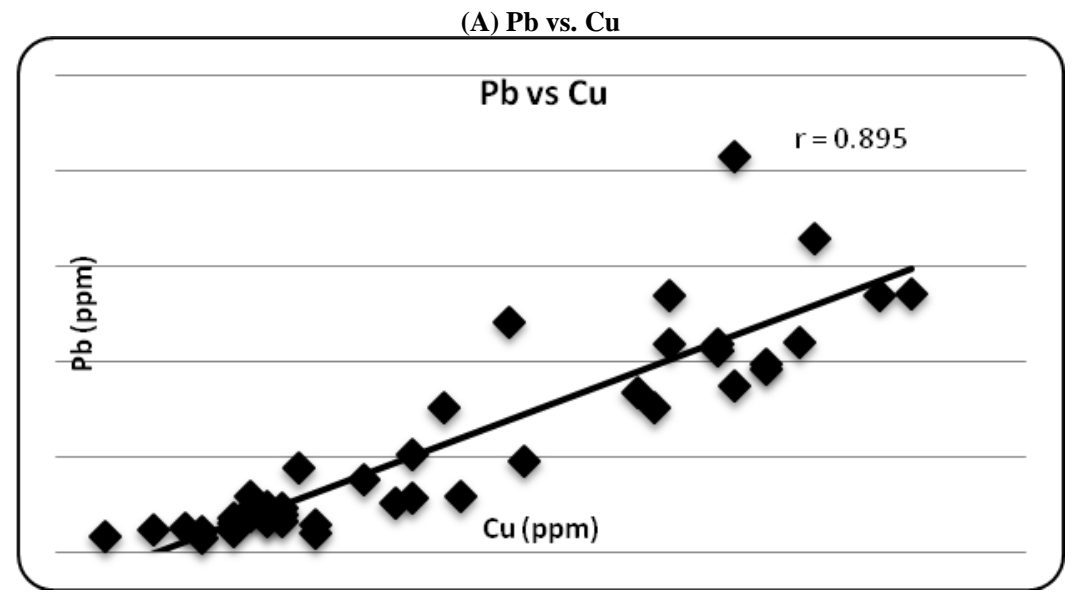

(B) Zn vs. Pb

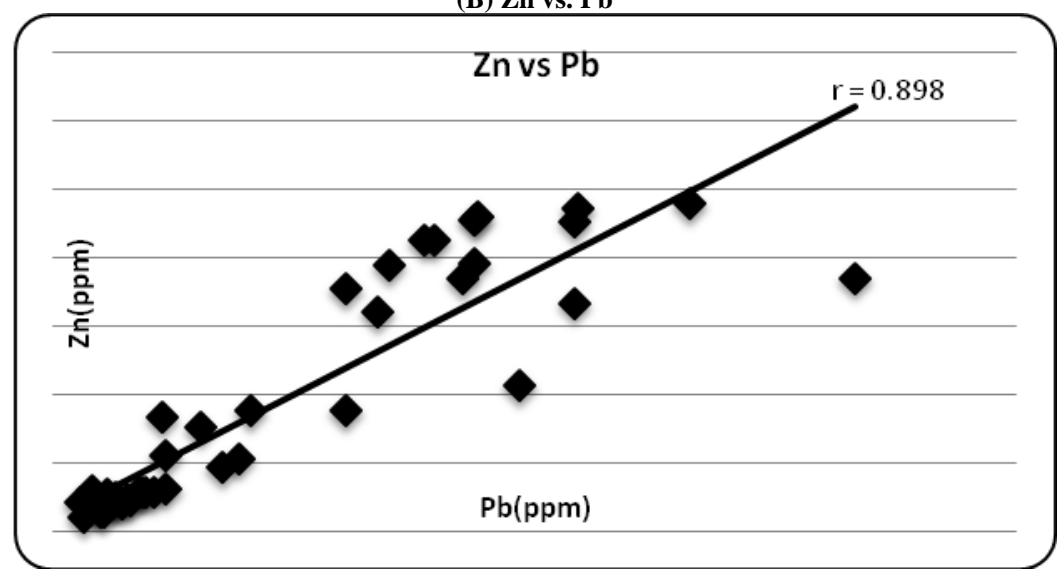


(C) Mn vs. Zn
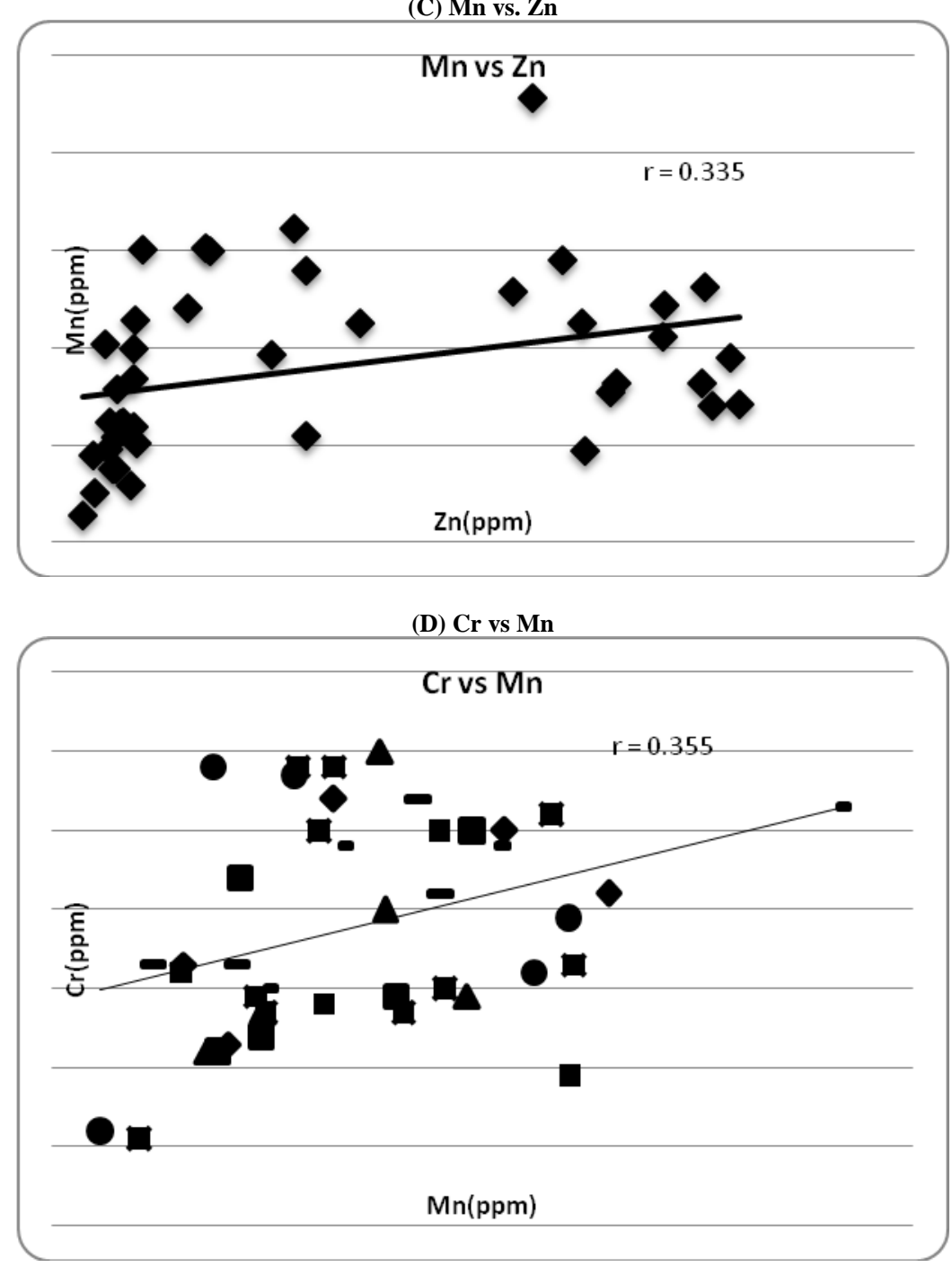

(E) Co vs Mn

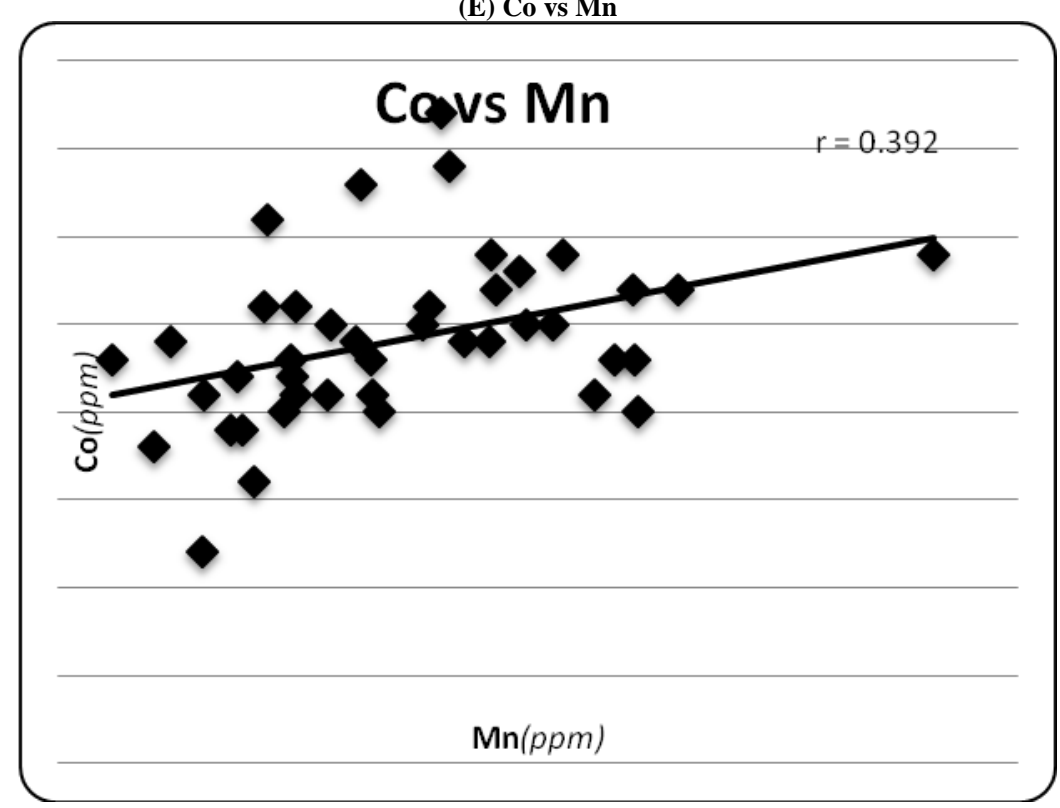

Fig. 5: (A-E): Relationships between Some of the Trace Elements in the Floodplain Soils of the Study Area.

\subsection{Factor analysis}

Factor analysis of different concentration values of the floodplain sediment of the study area has been carried out. Few trace elements have been considered for the present analysis. The analysis generated four factors which together account for $89.18 \%$ of variance. The rotated loadings, Eigen values, percentage of variance and cumulative percentage of variance of all the four factors are given in Table 3 ( $a$ and $b$ ). The first Eigen value is 4.80 which accounts for $47.99 \%$ of the total variance and this constitutes the first and main factor. The 
second and third Eigen values are 2.45 and 1.06 and these accounts for $24.49 \%$ and $10.57 \%$ respectively, of the total variance. The remaining Eigen value constitutes less than $10 \%$ of the total variance. The first factor (which accounts for $47.99 \%$ of the total variance) is characterised by very high loadings of $\mathrm{Cu}, \mathrm{Pb}, \mathrm{Zn}, \mathrm{V}$ and $\mathrm{Cr}$. These elements as also found in the correlation values (Table $3 \mathrm{a \& b}$ ), may have been enriched by same sources, most likely from domestic waste, effuents and vehicle related waste. The second factor (which accounts for $24.49 \%$ of the total variance) is mainly associated with very high loading of Th and La. These elements may have been enriched in the sediments by activities relating to similar pollution source draining into the River (e.g. urban waste). Factors 3 and Factors 4 are characterized by the dominance of only one variable each, such as Co (factor 3), Mn (factor 4) and together these two factors account for $16.69 \%$ of the total variance. These two elements main have been enriched in the sediment by same source, activities relating to soil weathering and leachate from automobile activities and other urban consumables like additives in chemical products.

Table 3: A) Principal Component Analyses of the Trace Elements in Ala- River Floodplain Sediment

\begin{tabular}{lllll}
\multicolumn{5}{c}{ Table 3: A) Principal Component Analyses of the Trace Elements in Ala- River Floodplain Sediment } \\
\hline Element & Factor 1 & Factor 2 & Factor 3 & Factor 4 \\
\hline $\mathrm{Cu}$ & 0.97 & -0.01 & -0.05 & 0.19 \\
$\mathrm{~Pb}$ & 0.94 & 0.04 & 0.04 & 0.06 \\
$\mathrm{Zn}$ & 0.95 & -0.09 & -0.02 & 0.18 \\
$\mathrm{Ni}$ & 0.34 & -0.74 & 0.21 & -0.06 \\
$\mathrm{Co}$ & 0.05 & 0.10 & 0.95 & 0.18 \\
$\mathrm{Mn}$ & 0.24 & 0.28 & 0.21 & 0.89 \\
$\mathrm{Th}$ & 0.15 & 0.90 & 0.12 & -0.06 \\
$\mathrm{~V}$ & 0.82 & 0.10 & 0.38 & 0.29 \\
$\mathrm{La}$ & 0.12 & 0.82 & 0.11 & \\
$\mathrm{Cr}$ & 0.96 & 0.01 & 0.08 & 0.61 \\
Eigen Value & 4.80 & 2.45 & 1.06 & 6.12 \\
\% of Variance & 47.99 & 24.49 & 10.57 & 89.18 \\
Cumulative \% & 47.99 & 72.48 & 83.06 & \\
\hline
\end{tabular}

Table 3: B) Summary of Elemental Associations of the Four-Factor Model and the Eigen Value.

\begin{tabular}{lll}
\hline Factor & Element Association & Eigen Value Ass \% \\
\hline F1 & Cu-Pb-Zn-V-Cr. & $47.99 \%$ \\
F2 & Th-La & $24.49 \%$ \\
F3 & Co & $10.57 \%$ \\
F4 & Mn & $6.12 \%$ \\
\hline
\end{tabular}

\subsection{Geo-accumulation index}

The geo-accumulation index (Igeo) values were interpreted (Table 4) with support of the classification of Muller, 1969 and 1981. Generally, the Igeo consists of 7 grades or classes. The highest concentration of $\mathrm{Pb}$ was recorded in location $21 \mathrm{~B}(3.47)$ and $\mathrm{Zn}$ was recorded in location 21A (2.19). The Igeo values revealed that the values of $\mathrm{Cu}, \mathrm{Ni}, \mathrm{Co}, \mathrm{Mn}, \mathrm{Th}, \mathrm{V}, \mathrm{La}$ and $\mathrm{Cr}$ in all locations fell into class 0 and class 1 . This indicated that the sediments in these locations were background concentration to unpolluted by these trace elements. All the sediments that were observed to be moderately to heavily polluted in Table 4 are those samples obtain from locations close to where high anthropogenic activities were taking place, like the relatively densely populated and commercial areas.

Table 4: Summary of Geo-Accumulation Index Calculated For Selected Elements in Floodplain Sediment

\begin{tabular}{lll} 
& Table 4: Summary of Geo-Accumulation Index Calculated For Selected Elements in Floodplain Sediment \\
\hline $\mathrm{Element}$ & Igeo Range & Interpretation \\
\hline $\mathrm{Cu}$ & -4.78 to -0.64 & Unpolluted \\
$\mathrm{Pb}$ & -1.42 to 3.47 & Unpolluted - Heavily polluted \\
$\mathrm{Zn}$ & -2.32 to 2.19 & Unpolluted- Moderately polluted \\
$\mathrm{Ni}$ & -3.81 to -1.96 & Unpolluted \\
$\mathrm{Co}$ & -1.64 to -0.02 & Unpolluted \\
$\mathrm{Mn}$ & -3.37 to 0.68 & Unpolluted \\
$\mathrm{Th}$ & -0.74 to 0.90 & Unpolluted \\
$\mathrm{V}$ & -2.53 to -0.95 & Unpolluted \\
$\mathrm{La}$ & -0.85 to 1.00 & Unpolluted \\
$\mathrm{Cr}$ & -3.77 to -1.32 & Unpolluted \\
\hline
\end{tabular}

\section{Conclusion}

Trace elements determinations have been carried out in the floodplain adjacent the stretch of Ala River in Akure largely within the developed area of the city, using the univariate, multivariate statistical and geo-reference map techniques such as frequency distribution, principal component analysis, and factor analysis. A total of forty-two Floodplain soils (top soils and sub soils) were collected to evaluate the chemical variation for $\mathrm{Cu}, \mathrm{Pb}, \mathrm{Zn}, \mathrm{Ni} \mathrm{Co}, \mathrm{Mn}, \mathrm{As}, \mathrm{Th}, \mathrm{Cd}, \mathrm{V}, \mathrm{La}$ and $\mathrm{Cr}$. Relatively high concentration of trace elements were found $\mathrm{Pb}(7-208 \mathrm{ppm}), \mathrm{Zn}(21-479 \mathrm{ppm})$ and Mn (138 - 2283ppm) among other selected elements. These indicate that these metals may be potentially hazardous to the environment. Elevated metal concentrations were found at locations close to active commercial and human waste discharges into the floodplain, indicating anthropogenic effect.

The results of correlation coefficient generated four factors which together account for $89.18 \%$ of variance. Trace elements $(\mathrm{Cu}, \mathrm{Pb}, \mathrm{Zn}$, $\mathrm{V}, \mathrm{Cr}$ ) with very high loadings may have been enriched by same sources, most likely from domestic waste, effuents and vehicle related waste. The elements (Th and La) may have been enriched in the sediments by activities relating to similar pollution source draining into the river. Other element such as Co and $\mathrm{Mn}$ together may have been enriched in the sediment by same source.

Further pollution level quantification of the trace metals revealed that $\mathrm{Pb}$ and $\mathrm{Zn}$ had reached significant pollutant status in the Ala River floodplain sediments as observed in the calculated geo-accumulation index in which some of the metals had status ranging from moderately polluted to heavily polluted. The relative active utilization of the all year round farm activies makes the environments of great concern, due to the possible bio availability of these potentially harmful elements in the biota. 


\section{Acknowledgements}

The authors are very grateful to Aladeji, A.J. and Folagbade, W.A. for their contribution in the fieldwork activities as well as sample preparations. Also, special thanks go to all the independent reviewers of this manuscript. They have assisted in improving the quality of the paper.

\section{References}

[1] Abimbola, A.F. and Olatunji, A.S. (2011): Urban geochemical mapping in Nigeria with some examples from southern Nigeria. In: Johnson, C.C., Demetriades, A., Locutura, J., Ottesen, R.T. (Eds.), Mapping the Chemical Environment of Urban Areas. John Wiley, Chichester, UK, pp. 570-580 (Chapter 32). https://doi.org/10.1002/9780470670071.ch32.

[2] Adekoya, J.A. (2003): Rocks and stones: treasure house for national prosperity. Inaugural Lecture Series 19, FUTA, Akure.

[3] Ajala, L.O., Onwukeme, V.I. and Mgbemena, M.N. (2014): Speciation of Some Trace Metals in FloodplainSoil of Eke-Mgbom, Afikpo, Nigeria: American Chemical Science Journal 4(6): 963-974. https://doi.org/10.9734/ACSJ/2014/11787.

[4] Ajayi, T.R., (1981): Statistical analysis of stream sediment data from the Ife-Ilesha area of southwest Nigeria. J. Geochem. Exploration. vol. 15, pp 539 548. https://doi.org/10.1016/0375-6742(81)90085-6.

[5] Akinlolu, F.A. and Akinade, S.O. (2011): Urban Geochemical Mapping in Nigeria with Some examples from Southern Nigeria: Mapping the chemical Environment of Urban Areas. First Edition.

[6] Akintola, A.I., Ikhane, P.R., Bankole, S.I. and Adeokurolere, D.M., (2013): Petrography and stream sediment geochemistry of Ede and its en virons south western Nigeria: International Research Journal of Geology and Mining (IRJGM) (2276-6618) Vol. 3(6) pp. 235-256.

[7] Alloway, B.J. (1995): Heavy metals in soils. Blackie and Son Ltd, Glasgow, London, p. 339. https://doi.org/10.1007/978-94-011-1344-1.

[8] Asowata, I.T., Badejo, O.O., Onifade, O.M. and Olukoya, F.F. (2015): Spatial Distribution of Trace Element of Ala River's Sediments, Akure, Southwestern Nigeria. Ife Journal of Science vol. 17, no. 1 (2015).

[9] Ayodele, J.T. and Oluyomi, C.D. (2011): Grass contamination by trace metals from road traffic. J. Environ. Chem. Ecotoxicol., 3(3): 60-67.

[10] Bidovec, M., Šajn, R. and Gosar, M. (1998): The use of recent overbank sediments in geochemical mapping of Slovenia (in Slovenian; English abstract). Geologija 41:275-317 https://doi.org/10.5474/geologija.1998.015.

[11] Bølviken, B., Bogen. J., Jartun, M., Langedal, M., Ottesen, R. and Volden, T. (2004): Overbank sediments: a natural bed blending sampling medium for large-scale geochemical mapping. Chemometrics and Intelligent Laboratory Systems 74:183-199 https://doi.org/10.1016/j.chemolab.2004.06.006.

[12] Cappuyns, V., Swennen, R., Vandamme, A., and Niclaes, M. (2006): Environmental impact of the former Pb-Zn minings and smelting in East Belgium. Journal of Geochemical Exploration 88:6-9 https://doi.org/10.1016/j.gexplo.2005.08.005.

[13] Cawthorn, R.G. (2001): A stream sediment geochemical re-investigation of the discovery of the platiniferous Merensky Reef, Bushveld Complex: Journal of Geochemical Exploration 72 pg.59-69. https://doi.org/10.1016/S0375-6742(00)00163-1.

[14] Ciszewski, D. (2002): Heavy metals in vertical profiles of the middle Odra River overbank sediments: evidence for pollution changes. Water, Air, and Soil Pollution 143:81-98 https://doi.org/10.1023/A:1022825103974.

[15] Davies, B.E. (1992): Trace metals in the environment: Retrospect and prospect In: Adriano DC (eds.). Biogeochemistry of trace metals. Lewis Publishers, Boca Raton Ann Arbor London, Tokyo, pp. 1-17.

[16] Davies, T.C. (2015): Urban Geochemistry of Lagos, Nigeria. IAgs $24^{\text {th }}$ Edition. Pg. 212-216

[17] Fatoki, O.S., Lujiza, N. and Ogunfowokan, A.O. (2002): Trace metal pollution in Umtata River. Water SA, 28: 183-189. https://doi.org/10.4314/wsa.v28i2.5160.

[18] Halamić, J., Galović, L. and Šparica, M. (2003): Heavy Metal (As, Cd, Cu, Hg, Pb, and Zn) Distribution in Topsoil Developed on Alluvial Sediments of the Drava and Sava Rivers in NW Croatia. Geologia Croatica 56/2:215-232

[19] Hendershot, W. (2005): Digging up the dirt. The Reporter, Mc. Grill, 27(9): 37

[20] Igwe, C.A., Zarei, M. and Stanr, K. (2005): Mineral and elemental distribution in soils formed on the River Niger floodplain, eastern Nigeria. Australian Journal of Soil Research, 2005, 43, pp147-158 https://doi.org/10.1071/SR04046.

[21] Langedall, M. and Ottesen, R.T. (1998): Airborne pollution in five drainage basins in Eastern Finmark, Norway: an evaluation of overbank sediments as sampling medium for environmental studies and geochemical mapping. Water, Air and Soil Pollution 101:377-398 https://doi.org/10.1023/A:1004954229477.

[22] Lapworth, D.J., (2012): Geochemical mapping using stream sediments in west-central Nigeria: Implications for environmental studies and mineral exploration in West Afric: Applied Geochemistry Publication 27, 1035-1052. https://doi.org/10.1016/i.apgeochem.2012.02.023.

[23] Lapworth, D.J., Katherine, V., Roger, M.K., Christopher, C.J., Emmanuel, A., Michael, A.A., Tunde, M.A., Olugbenga, A.O., Birgitta, B., Mikael, E., Paul, A.E., Robert, T.L., John, R., Michael, J.W., Simon, J.K. and Peter, E.J. (2011): Geochemical mapping using stream sediments in westcentral Nigeria: implications for environmental studies and mineral exploration in West Africa. Draft paper Vol.6 Applied Geochemistry.Pg.1-66. https://doi.org/10.1016/j.apgeochem.2012.02.023

[24] Levinson, A. A. 1974. Introduction to Exploration Geochemistry. Applied Publication Limited, Calgary. $1965 \mathrm{pp}$.

[25] Macklin, M.G., Ridgway, J., Passmore, D.G. and Rumsby, B.T. (1994): The use of overbank sediment geochemical mapping and contamination assessment: results from selected English and Welsh floodplains. Applied Geochemistry 9:689-700 https://doi.org/10.1016/0883-2927(94)90028-0.

[26] Macklin, M.G., Brewer, P.A., Hudson-Edwards, K.A., Bird, G., Coulthard, T.J., Dennis, I.A., Lechler, P.J., Miller, J.R. and Turner, J.N. (2006): A geomorphological approach to the management of rivers contaminated by metal mining. Geomorphology $79.423-447$ https://doi.org/10.1016/j.geomorph.2006.06.024.

[27] McConnel, J.W., Finch, C., Hall, G. and Davenport, P.H. (1993): Geochemical mapping employing active and overbank stream-sediment, lake sediment and lake water in two areas of New Foundland. Journal of Geochemical Exploration 49:123-143. https://doi.org/10.1016/03756742(93)90041-J.

[28] Muller G., (1969): Index of geoaccumulation in sediments of the Rhine River. Geojournal, 2: pp 108-118.

[29] Muller G., (1979): Schwermetalle in den sedimenten des Rhneins-VErain derungen Seit 1971. Umshau 79 (24): pp 774-789.

[30] Nigeria Geological Survey Agency (NGSA) (2006): Published by the Authority of the Federal Republic of Nigeria.

[31] Nriagu, J.O. (1986): Chemistry of the river Niger, I: major ions, II: trace metals. Sci. Tot. Environ. 58: 81-92. https://doi.org/10.1016/00489697(86)90079-3.

[32] Odeyemi, I.B. (1988): Lithostratigraphy and structural relationships of the Upper Precambrian Metasediments in Igarra area, southwestern Nigeria. In: Oluyide, P. O., W. C. Mbonu, A. E. Ogezi, I. G. Egbuniwe, A. C. Ajibade, and A. C. Umeji. (Editors), Precambrian geology of Nigeria. Publ. GSN. pp 111125 .

[33] Odor, L., Horváth, I. and Fügedi, U. (1997): Low-density geochemical mapping in Hungary. Journal of Geochemical Exploration 60:55-66 https://doi.org/10.1016/S0375-6742(97)00025-3.

[34] Olarewaju, V. O. (2006): The Charnockitic Intrusive of Nigeria, In: Basement Complex of Nigeria and its Mineral Resources, Oshin, O. (Ed.), Akin Jinad Co., Ibadan, Nigeria, pg.: 45-70.

[35] Olatunji A.S and Abimbola A.F. (2010). Geochemical Evaluation of the Lagos Lagoon sediments and water. World Applied Science Journal, 9 (2) 178-193. 
[36] Olatunji, A. S; Abimbola, A. F and Asowata, I. T 2014. Geochemical Evaluation of Soils and Road Deposited Sediments of Benin City Using GIS and Multi-variance Approaches. British Journal of Applied Science \& Technology (SCIENCEDOMAIN) 4(18): 2590-2606 https://doi.org/10.9734/BJAST/2014/9060.

[37] Ondo State Ministry of Economic Planning and Budget (2010): The publication of facts and figures of Ondo State of Nigeria. Research and Statistics Dept., 7-9

[38] Ondo State Ministry of Lands, Housing \& Environment (2000): Ecological Report and Engineering design for flood and erosion control works in Idanre Township. MLHE, Akure, Ondo State, Nigeria.

[39] Ottesen, R.T., Bogen, J., Bolviken, B. and Volden, T. (1989): Overbank sediment: a representative sampling medium for regional geochemical mapping. Journal of Geochemical Exploration, 32, 257-277. https://doi.org/10.1016/0375-6742(89)90061-7.

[40] Ottesen, R.T., Bogen, J., Bolviken, B., Volden, T. and Haugland, T. (2000): Geochemical Atlas of Norway. Geological Survey of Norway, Trondheim, $141 \mathrm{pp}$.

[41] Owoyemi, F.B. (1996): A Geologic-geophysical Investigation of Rain-induced Erosional Features in Akure Metropolis. Unpublished M.Sc. Thesis Federal University of Technology, Akure, pp. $11-18$

[42] Pavlovic. G., Prohic, E. and Tibljas, D. (2004): Statistical assessment of geochemical pattern in overbank sediments of the river Sava, Croatia. Environmental Geology 46:132-143.

[43] Pramod, S. and Rajamani, V. (2001): Geochemistry of the Floodplain Sediments of the Kaveri River, Southern India: Journal of Sedimentary Research, VOL. 71, NO. 1, P. 50-60 https://doi.org/10.1306/042800710050.

[44] Rognerud, S., Hongve, D., Fjeld, E., and Ottesen, R.T. (2000): Trace metal concentrations in lake and overbank sediments in southern Norway. Environmental Geology 39(7):723-732 https://doi.org/10.1007/s002540050486.

[45] Romic, M. and Romic, D. (2003): Heavy metals distribution in agricultural topsoils in urban area. Environmental Geology 43:795-805 https://doi.org/10.1007/s00254-002-0694-9.

[46] Swennen, R., Van Keer, I. and De Voos, W. (1994): Heavy metal concentration in overbank sediments of the Gaul river (East Belgium): Its relation to former $\mathrm{Pb}-\mathrm{Zn}$ mining activities. Environmental Geology 24:12-21 https://doi.org/10.1007/BF00768072.

[47] Swennen, R., Van Der Sluys, J., Hindel, R. and Brusselmans, A. (1998): Geochemistry of overbank and high-order stream sediments in Belgium and Luxemburg: a way to assess environmental pollution. Journal of Geochemical Exploration 62:67-79 https://doi.org/10.1016/S03756742(97)00056-3.

[48] Swennen, R. and Van der Sluys, J. (2002): Anthropogenic impact on sediment composition and geochemistry in vertical overbank profiles of river alluvium from Belgium and Luxembourg. Journal of Geochemical Exploration, 75, 93-105. https://doi.org/10.1016/S0375-6742(02)00199-1.

[49] Turekian, K.K and Wedepohl L.H, 1961. Distribution of elements in major units of the earth crust. Bulleting of Geological Society of America, 72: 175 - 191. https://doi.org/10.1130/0016-7606(1961)72[175:DOTEIS]2.0.CO;2. 